\title{
HUBUNGAN RESILIENSI DENGAN INFERTILITY-RELATED STRESS PADA WANITA
}

\author{
I Made Ari Nugraha Saputra, Diah Widiawati Retnoningtias, dan I Rai Hardika \\ Program Studi Psikologi, Universitas Dhyana Pura \\ Jalan Raya Padang Luwih, Dalung, Kuta Utara, Badung, Bali, 80361 \\ Email: arinugraha901@gmail.com
}

\begin{abstract}
ABSTRAK
Tujuan penelitian ini adalah untuk melihat hubungan antara resiliensi dengan infertility-related stress. Resiliensi adalah kualitas diri individu untuk bangkit atau bertahan dalam situasi sulit, sedangkan infertility-related stress atau stres infertilitas adalah stres yang muncul sebagai akibat dari infertilitas yang dialami. Tipe penelitian ini adalah kuantitatif dengan metode uji korelasional. Partisipan dalam penelitian ini adalah wanita yang mengalami infertilitas dan bertempat tinggal di Bali $(n=119)$ yang diperoleh dengan menggunakan teknik purposive sampling. Instrumen yang digunakan untuk mengukur variabel resiliensi adalah Connor-Davidson Resilience Scale (CD-RISC), sedangkan untuk mengukur variabel infertility-related stress menggunakan Copenhagen Multi Central Psychosocial InfertilityFertility Problem Stress Scale (COMPI-FPSS). Kedua alat ukur tersebut telah diadaptasi ke dalam Bahasa Indonesia, masing-masing memiliki nilai reliabilitas sebesar .923 untuk CD-RISC dan .938 untuk COMPI-FPSS. Hasil dalam penelitian ini adalah terdapat hubungan antara resiliensi dengan infertility-related stress dengan nilai signifikansi .012 $(p<.05)$ dengan koefisien korelasi menunjukkan arah hubungan negatif dan kekuatan hubungan yang lemah (-.229). Hasil tersebut memiliki arti bahwa makin tinggi tingkat resiliensi yang dimiliki, maka makin rendah tingkat stres infertilitas yang dirasakan dan begitu pula sebaliknya.
\end{abstract}

Kata kunci: resiliensi; stres; infertility-related stress; infertilitas; wanita infertilitas

\section{THE CORRELATION OF RESILIENCE TO INFERTILITY-RELATED STRESS IN WOMEN}

\begin{abstract}
The purpose of this study is to examine the relationship between resilience and infertility-related stress. Resilience is the quality of individual self to rise or survive in difficult situations, while infertility-related stress is a stress that arises as a result of infertility experienced. This type of research is quantitative with correlational test methods. Participants in this study were women who experienced infertility and residing in Bali $(n=119)$ obtained using purposive sampling technique. The instrument used to measure the resilience variable is the Connor Davidson Resilience Scale (CD-RISC). Theinfertility-related stress variable was measured by the Copenhagen Multi Central Psychosocial Infertility-Fertility Problem Stress Scale (COMPI-FPSS). Both instruments have been adapted intoIndonesian language, each of which has a reliability value of .923 for CD-RISC and .938 for COMPI-FPSS. Results show that there is a weak negative relationship between resilience and infertility-related stress $(r=-.229, p$ $=.012)$. The results indicate that the higher resilience that they have, the lower infertility-related stress they feel and vice versa.
\end{abstract}

Keywords: resilience; stress; infertility-related stress; infertility; women infertility 


\section{PENDAHULUAN}

Pernikahan menjadi ikatan sosial maupun pribadi yang membentuk dan meresmikan suatu hubungan menjadi sebuah keluarga dengan tujuannya masing-masing (Dewi, 2014). Tujuan pernikahan adalah mendapatkan keturunan atau anak (Yani, 2018). Kehadiran anak dalam keluarga dianggap dapat meningkatkan kepuasan pernikahan dan menguatkan komitmen dari suatu pasangan (Mardiyan \& Kustanti, 2016). Selain itu, anak juga dianggap sebagai pembawa kebahagiaan orang tua, penerus keturunan, aset keluarga, serta penjaga nama baik dan pelindung keluarga (Prasanti, 2013). Namun, terdapat pula pasangan yang masih belum memperoleh keturunan meski telah lama menikah. Hal ini disebabkan oleh infertilitas. Infertilitas diartikan sebagai ketidakmampuan pasangan suami-istri untuk memperoleh keturunan secara biologis walaupun telah menikah minimal satu tahun, berhubungan intim secara teratur, dan tidak menggunakan alat kontrasepsi (Hidayah, 2007). Infertilitas juga diartikan sebagai ketidakmampuan untuk hamil, ketidakmampuan mempertahankan kehamilan, dan ketidakmampuan untuk menghadirkan kehidupan baru (World Health Organization Infertility, 2012).

WHO (2012) menyebutkan bahwa dari seluruh populasi pasangan suami istri di dunia, sekitar 5080 juta pasangan mengalami infertilitas. Sementara itu, Survei Sosial Ekonomi Nasional BKKBN tahun 2015 menyebutkan bahwa terdapat $10-11 \%$ dari 48.609 juta pasangan usia subur yang mengalami infertilitas di Indonesia (Hapsari \& Septiani, 2015). Program In Vitro Fertilization (IVF) atau program bayi tabung menjadi salah satu cara pasangan untuk memperoleh keturunan (Hapsari \& Septiani, 2015). Indonesia sendiri memiliki 32 klinik bayi tabung yang tersebar di 13 kota dan 10 provinsi (Saraswati, 2015). Selanjutnya, Indonesian Association For in Vitro Fertilization's National Report menyatakan bahwa Bali menjadi provinsi tertinggi ketiga setelah Jakarta dan Surabaya dengan jumlah klinik bayi tabung terbanyak yakni RSUP Sanglah, Bali Royal Hospital (BROS), Puri Bunda, dan Prima Medika ("Program Bayi Tabung di Bali").

Infertilitas dapat dialami oleh pria maupun wanita. Infertilitas pada pria disebabkan karena faktor koitus, ejakulasi, pekerjaan, usia dan gaya hidup, sedangkan infertilitas pada wanita disebabkan oleh adanya masalah serviks, tuba, ovarium, vagina, uterus dan gangguan ovulasi (Saraswati, 2015). Kondisi infertilitas yang disebabkan oleh wanita yakni sebesar $45 \%$, laki-laki $40 \%$, dan faktor tidak diketahui (idiopatik) sebesar 15\% (Lestari \& Sari, 2015). Indriyani (2011) juga menyebutkan kasus infertilitas disebabkan oleh wanita sebesar $40 \%$, disebabkan oleh pria $30 \%$ dan disebabkan oleh keduanya sebesar $30 \%$.

Penelitian yang berkaitan dengan infertilitas menyatakan bahwa pihak istri mengalami stres, kecemasan, dan depresi lebih besar dari pihak suami. Hal ini biasanya juga diperparah dengan adanya Undang-Undang Republik Indonesia Nomor 1 Tahun 1974 Pasal 4 Ayat 2 (c) mengenai pemberian kesempatan pada pihak suami untuk menikah lagi jika belum mendapatkan keturunan dari pihak istri, adanya perlakuan yang berbeda oleh masyarakat, serta menurunnya tingkat kesuburan ketika menginjak usia 35 tahun (Musa et al., 2014; American Society for Reproductive Medicine, 2016; Susanti \& Nurchayati, 2019).

Respons awal wanita yang mengalami infertilitas adalah menutup diri, merasa bersalah, cemas, tidak berdaya, dan juga stres (Nurhasyanah, 2012). Individu yang mengalami stres akibat dari infertilitas disebut dengan infertility-related stress atau stres infertilitas. Stres ini dapat berasal dari dalam diri maupun luar diri individu tersebut (Newton et al., 1999). Stres infertilitas yang bersumber dari dalam diri meliputi keharusan untuk meluangkan waktu menjalani pengobatan atau terapi, kedisiplinan menjalani pantangan selama pengobatan, dan harapan yang sangat tinggi untuk menghadirkan anak di dalam keluarga. Di samping itu, stres infertilitas yang bersumber dari eksternal pasangan tersebut yakni tuntutan lingkungan untuk segera memperoleh keturunan dan besarnya biaya pengobatan yang telah dikeluarkan (Kasdu, 2002; Nurkhasanah, 2016). Gejala wanita yang mengalami stres infertilitas yaitu adanya perasaan sedih, cemas, frustrasi, marah, perasaan kosong, dan timbul rasa iri pada pasangan yang telah memiliki anak (Apfel \& Keylor, 2002). Stres infertilitas ini berlangsung secara periodik yakni setiap bulan, bersamaan dengan datangnya menstruasi yang dialami oleh pihak wanita (Ratna, 2000).

Faktor-faktor yang memengaruhi infertility-related stress yaitu gender, age, fertility history, educational level, dan risk factors (Newton et al., 1999; Zurlo, Volta, \& Vallone, 2017). Sementara itu, Schmidt \& Bull (2006) menyatakan bahwa terdapat tiga aspek dari infertility-related stress yang meliputi (1) Marital Domain, terkait dengan seberapa besar infertilitas memengaruhi hubungan pernikahan dan 
seksual mereka dengan pasangan, (2) Social Domain, yakni infertilitas yang dialami memengaruhi hubungan sosial mereka dengan keluarga, teman, dan rekan kerja, dan (3) Personal Domain, yakni kondisi infertilitas yang dialami memengaruhi kesehatan fisik dan kesehatan mental mereka.

Wanita yang mengalami infertilitas memerlukan regulasi emosi yang baik, mampu mengontrol sikap impulsif dirinya, bersikap optimis, mampu menganalisis masalah, memiliki empati terhadap orang lain, memiliki efikasi diri dan memiliki motivasi untuk mencapai tujuan yang diinginkan serta membutuhkan dukungan dari orang di sekitarnya (Ayu, 2012). Hal tersebut merupakan bentuk kemampuan yang harus dimiliki individu untuk mempertahankan stabilitas psikologis dalam menjalani kehidupannya yang disebut dengan resiliensi (Keye \& Pidgeon, 2013). Resiliensi juga diartikan sebagai ide yang mengacu pada kapasitas sistem dinamis untuk bertahan atau pulih dari gangguan (Masten, 2007). Connor \& Davidson (2003) menyebutkan bahwa terdapat lima aspek terkait dengan resiliensi, yaitu: (1) personal competence, high standard, and tenacity yang menunjukkan bahwa individu merasa mampu mencapai tujuannya dalam situasi kemunduran atau kegagalan, (2) trust in one's instincts, tolerance of negative affect, and strengthening effects of stress yang berkaitan dengan ketenangan dan coping terhadap stres, berpikir dengan hati-hati, dan fokus meskipun dalam masalah, (3) positive acceptance of change, and secure relationships, yaitu kemampuan beradaptasi dengan perubahan yang dihadapinya, (4) self-control dalam pencapaian tujuan dan bagaimana meminta bantuan pada orang lain, (5) spiritual influences, keyakinan akan Tuhan dan nasib.

Meningkatnya resiliensi yang dimiliki seseorang dapat mengembangkan keterampilan hidup seperti cara berkomunikasi, kemampuan realistis dalam membuat rencana hidup dan kemampuan untuk mengambil langkah yang tepat bagi hidupnya (Rojas, 2015). Bentuk resiliensi pada wanita yang mengalami infertilitas dimana mereka akan cenderung berusaha untuk sabar, fokus pada masa depan, menerima apa yang terjadi padanya, dan pasrah dengan keadaan yang dialaminya (Pandanwati \& Suprapti, 2012). Beberapa penelitian menunjukkan bahwa terdapat korelasi antara resiliensi dan stres, tetapi peneliti belum menemukan penelitian mengenai hubungan resiliensi dengan infertility-related stress pada wanita yang menagalmi infertilitas di Indonesia, khususnya di Bali. Alasan peneliti melakukan penelitian ini di Bali karena Bali merupakan provinsi dengan klinik bayi tabung ketiga terbanyak di Indonesia. Keinginan ini juga diperkuat oleh hasil wawancara peneliti dengan beberapa subjek wanita yang mengalami infertilitas salah satunya subjek BD (36 tahun) yang menyatakan "kadang ngerasa sedih sih ketika ditanya tentang anak, apalagi diomongin sama tetangga, udah tua kok belum punya anak ", serta adanya orang terdekat peneliti yang mengalami infertilitas selama beberapa tahun dan mampu bertahan dalam situasi tersebut hingga memperoleh keturunan.

\section{METODE}

Penelitian ini menggunakan metode penelitian kuantitatif korelasional, di mana penelitian korelasional didefinisikan sebagai penelitian yang memberikan deskripsi gambaran mengenai hubungan antara dua variabel atau lebih tanpa adanya manipulasi dari variabel tersebut (Fraenkel et al., 2012). Penelitian ini bertujuan untuk mengetahui hubungan resiliensi dengan infertility-related stress pada wanita yang mengalami infertilitas di Bali.

Partisipan dalam penelitian ini adalah wanita yang memenuhi kriteria inklusi. Adapun kriteria inklusi dalam penelitian ini adalah wanita yang telah menikah minimal satu tahun, belum memiliki keturunan, tidak sedang menunda kehamilan dan bertempat tinggal atau berdomisili di Bali. Sedangkan kriteria ekslusi dalam penelitian ini adalah wanita yang telah menikah kurang dari satu tahun, telah memiliki keturunan, dan tidak berdomisili di Bali.

Partisipan dalam penelitian ini berjumlah 119 orang wanita yang berdomisili di kabupaten yang ada di Bali. Adapun yang pertama yakni Kota Denpasar, sebanyak 61 partisipan (51.2\%), kemudian Kabupaten Badung sebanyak 33 partisipan (27.8\%), Kabupaten Tabanan sebanyak sebelas partisipan (9.2\%), Kabupaten Gianyar sebanyak tujuh partisipan (5.9\%), Kabupaten Buleleng sebanyak empat partisipan (3.3\%), Kabupaten Karangasem sebanyak dua partisipan (1.7\%), dan Kabupaten Jembrana sebanyak satu partisipan (1.7\%). Sementara itu, pengelompokan berdasarkan data yang diperoleh mengenai durasi pernikahan dan durasi menunggu kehadiran anak di masing-masing partisipan dikelompokkan sebagai berikut: durasi satu sampai lima tahun sebanyak 86 partisipan (72.3\%), durasi enam sampai sepuluh 
tahun sebanyak 25 partisipan (21\%), durasi 11 sampai 15 tahun sebanyak lima partisipan (4.2\%), dan durasi 16 sampai 20 tahun sebanyak tiga partisipan (2.5\%).

Populasi dalam penelitian ini tergolong dalam populasi infinit yang jumlah anggota populasinya tidak dapat diketahui jumlahnya secara pasti (Supardi, 1993). Hal ini disebabkan oleh jumlah populasi yang terlalu besar atau jumlah dari wanita yang mengalami infertilitas di Bali tidak terbatas sehingga penghitungan jumlah sampel dalam penelitian ini dilakukan dengan cara satu perempat kali $z$ score derajat kepercayaan $(\alpha)$ per toleransi kesalahan $(E)$ kuadrat yang merupakan rumus dari Subagyo dan Djarwanto (2005) dan didapatkan jumlah sampelnya adalah sebanyak 119 partisipan. Pengambilan sampel pada penelitian ini menggunakan teknik purposive sampling, yakni teknik yang menentukan sampel berdasarkan adanya kriteria yang telah ditentukan (Sugiyono, 2016). Adapun kriteria purposive sampling dalam penelitian ini yaitu wanita yang telah menikah minimal satu tahun namun belum memiliki anak atau keturunan dan bertempat tinggal atau berdomisili di Bali.

Teknik pengambilan data yang digunakan dalam penelitian ini adalah wawancara semiterstruktur dan penyebaran kuesioner yang dilakukan secara tatap muka menggunakan metode paper and pencil serta secara daring melalui google form. Alat ukur dalam penelitian ini menggunakan skala Likert, yakni skala yang digunakan untuk menentukan tingkat persetujuan responden terhadap suatu pernyataan sesuai dengan pengetahuan dan hal yang sebenarnya terjadi (Maryuliana, Subroto \& Haviana, 2016). Alat ukur yang digunakan dalam penelitian ini terdiri dari dua alat ukur yaitu (1) Copenhagen Multi Central Psychosocial Infertility-Fertility Problem Stress Scale (COMPI-FPSS) yang dikembangkan oleh Sobral, et al. (2017) dan telah diterjemahkan ke dalam bahasa Indonesia dengan jumlahskala sebanyak sembilan butir. Alat ukur ini digunakan untuk mengukur variabel infertility-related stress dengan nilai validitas dari alat ukur COMPIFPSS menunjukkan nilai korelasi total pada seluruh butir skala berkisar antara .733-.912, lalu hasil uji reliabilitas menunjukkan nilai sebesar 0.938. (2) Connor Davidson-Resilience Scale (CD-RISC) yang dibuat oleh Connor \& Davidson (2003) dan telah diadaptasi ke dalam bahasa Indonesia oleh Azzahra (2017) dengan jumlah skala sebanyak 25 butir. Alat ukur ini digunakan untuk mengukur variabel resiliensi dengan hasil uji validitas dari alat ukur CD-RISC berkisar antara 0.372-0.771, kemudian untuk uji reliabilitas menunjukkan nilai sebesar 0.923 .

Peneliti melakukan uji hipotesis untuk melihat hubungan antara infertility-related stress dengan resiliensi menggunakan teknik korelasi Spearman's Rank sebab data dalam penelitian ini tidak berdistribusi normal. Jika nilai signifikansi dalam uji hipotesis ini menunjukkan taraf signifikansi lebih kecil dari .05 atau $p<.05$ maka dapat dikatakan bahwa terdapat hubungan di antara kedua variabel dan begitu juga sebaliknya.

\section{HASIL DAN PEMBAHASAN}

Peneliti melakukan pengkategorisasian partisipan berdasarkan rendah, sedang, dan tinggi pada variabel dalam penelitian ini. Adapun hasilnya terdapat pada Tabel 1 di bawah ini.

Tabel 1. Kategorisasi Partisipan

\begin{tabular}{ccc}
\hline Variabel & Kategori & Frekuensi \\
\hline \multirow{3}{*}{$\begin{array}{c}\text { Infertility- } \\
\text { related } \\
\text { stress }\end{array}$} & Rendah & $25(21.0 \%)$ \\
\cline { 2 - 3 } & Sedang & $81(68.1 \%)$ \\
\cline { 2 - 3 } Resiliensi & Tinggi & $13(10.9 \%)$ \\
\cline { 2 - 3 } & Rendah & $15(12.6 \%)$ \\
\cline { 2 - 3 } & Sedang & $86(72.3 \%)$ \\
\hline
\end{tabular}

Berdasarkan tabel kategorisasi di atas, didapatkan hasil bahwa dari 119 partisipan dalam penelitian ini, sebanyak 25 partisipan (21.0\%) memiliki infertility-related stress dengan kategori rendah, kemudian sebanyak 81 partisipan $(68.1 \%)$ tergolong ke dalam kategori sedang, sedangkan sebanyak 13 partisipan 
$(10.9 \%)$ tergolong ke dalam kategori tinggi. Selanjutnya, terkait dengan resiliensi di 119 partisipan, didapatkan bahwa sebanyak 15 partisipan (12.6\%) memiliki resiliensi yang tergolong rendah, kemudian sebanyak 86 partisipan $(72.3 \%$ ) memiliki resiliensi yang tergolong sedang, dan sebanyak 18 partisipan (15.1\%) memiliki resiliensi yang tergolong tinggi. Hasil tersebut menunjukkan di masing-masing variabel dalam penelitian ini sebagian besar partisipan tergolong ke dalam kategori sedang yakni 81 partisipan (68.1\%) pada infertility-related stress dan 86 partisipan (72.3\%) pada resiliensi. Hasil uji hipotesis yang dilakukan oleh peneliti dapat dilihat pada Tabel 2 berikut.

Tabel 2. Hasil Uji Hipotesis

\begin{tabular}{cccc}
\hline Skala & \multicolumn{3}{c}{ Spearman's Rank Rho } \\
\hline COMPI- & Correlation & Sig. & N \\
FPSS * CD- & Coefficient & . & \\
\cline { 2 - 4 } RISC & -.229 & .012 & 119 \\
\hline
\end{tabular}

Berdasarkan tabel di atas, uji hipotesis yang menggunakan teknik Spearman's Rank Rho dalam penelitian imi menunjukkan nilai signifikan sebesar 012 di mana nilai ini lebih kecil daripada .05. Oleh karena itu, dapat disimpilkan dari hasi tersebut bahwaterdapat hubungan antara resiliensi dengan infertilityrelated stress pada wanita yang mengalami infertilitas di Bali. Hasil uji yang menggunakan teknik Spearman's Rank Rho tersebut juga menghasilkan nilai koefisien korelasi. Nilai ini bertujuan untuk mengetahui seberapa kuat hubungan yang dimiliki di antara kedua variabel. Pada penelitian ini koefisien korelasinya menunjukkan nilai sebesar .229, di mana nilai tersebut mengartikan bahwa tingkat hubungan antara variabel resiliensi dengan variable infertility-related stress memiliki hubungan yang lemah (Periantalo, 2016). Hasil uji korelasi menggunakan Spearman's Rank Rho di atas juga menunjukkan bahwa terdapat hubungan negatif pada nilai koefisien korelasi antara kedua variabel. Hal ini memiliki arti bahwa makin tinggi resiliensi yang dimiliki oleh partisipan, maka makin rendah infertility-related stress yang dirasakannya dan begitu juga sebaliknya. Makin rendah resiliensi yang dimiliki oleh partisipan, maka makin tinggi infertility-related stress yang dirasakannya.

Hasil penelitian ini sejalan dengan penelitian sebelumnya yang dilakukan oleh Li et al. (2019) pada wanita yang mengalami infertilitas di Cina, di mana ditemukan bahwa terdapat korelasi negatif antara resiliensi dengan infertility-related stress. Hasil yang sama juga ditemukan pada penelitian yang dilakukan oleh Herrmann, et al. (2011) yang menunjukkan korelasi negatif antara resiliensi dengan infertility-spesific distress pada wanita infertilitas di Jerman pada semua aspek FPI (Fertility Problem Inventory) yang digunakan. Penelitian lain yang dilakukan di Amerika oleh Sexton, Byrd, \& Kluge (2010) juga menunjukkan hasil yang sama yakni adanya korelasi negatif antara resiliensi dengan infertility-related stress pada wanita yang mengalami infertilitas. Peneliti juga melakukan uji korelasi antara infertilityrelated stress dengan skor total dari kelima aspek resiliensi untuk memastikan hubungan yang dimiliki antara kedua variabel. Adapun hasilnya dapat dilihat pada Tabel 3 berikut. 
Tabel 3. Uji Korelasi COMPI dengan Aspek

Resiliensi

\begin{tabular}{lcc}
\hline \multicolumn{1}{c}{ Aspek Resiliensi } & $\begin{array}{c}\text { Correlation- } \\
\text { Coefficient }\end{array}$ & $\begin{array}{c}\text { Sig. (2- } \\
\text { tailed) }\end{array}$ \\
\hline $\begin{array}{l}\text { Personal competence, } \\
\text { high standards, and } \\
\text { tenacity, }\end{array}$ & -.288 & .001 \\
$\begin{array}{l}\text { Trust in one's instincts, } \\
\text { tolerance of negative } \\
\text { affect, and strengthening } \\
\text { effects of stress }\end{array}$ & -.272 & .003 \\
$\begin{array}{l}\text { Positive acceptance of } \\
\text { change, and secure } \\
\text { relationships, }\end{array}$ & -.265 & .004 \\
\hline $\begin{array}{l}\text { Self-control } \\
\text { Spiritual influences }\end{array}$ & -.150 & .103 \\
\hline
\end{tabular}

Berdasarkan tabel di atas, terdapat tiga aspek yang memiliki nilai signifikansi $<.05$ yang artinya terdapat korelasi antara infertility-related stress dengan aspek resiliensi tersebut serta terdapat dua aspek yang tidak berkorelasi secara langsung karena memiliki nilai signifikansi $>.05$. Adapun ketiga aspek yang berkorelasi tersebut yang pertama yaitu personal competence, high standards, and tenacity. Penelitian Ulfah \& Mulyana (2014) menyatakan bahwa wanita dengan segala kemampuannya harus dapat berjuang melawan stres sebagai dampak buruk yang diakibatkan oleh infertilitas. Individu yang cenderung ketika mengarah pada perubahan ketika pengambilan keputusan dan penyelesaian masalah, akan menjadi pribadi yang lebih kuat dan cenderung memiliki harapan mengenai keinginan dan masa depannya (Reivich \& Shatte, 2002). Kemampuan yang dimiliki individu dalam menghadapi stres tentunya berbeda-beda sehingga tidak menutup kemungkinan bahwa tidak semua partisipan dalam penelitian ini memiliki kemampuan yang baik dalam menghadapi stres infertilitas (Komalasari \& Septiyanti, 2017). Oleh karena itu, hal ini pun dapat menjadikan aspek personal competence, high standards, and tenacity berkorelasi dengan infertility-related stress.

Aspek yang kedua adalahtrust in one's instincts, tolerance of negative affect, and strengthening effects of stress. Penelitian yang dilakukan oleh Estherline dan Widayanti (2016) menyatakan bahwa infertilitas yang dialami wanita juga akan memengaruhi fokusnya terhadap kegiatan sehari-hari karena hanya berfokus terhadap situasi infertilitasnya saja. Ketika wanita yang mengalami infertilitas ketika dalam keadaan tertekan karena stres yang dialaminya, ia akan cenderung membayangkan betapa bahagianya jika memiliki anak (Jordan \& Revenson, 1999). Terkait dengan hal tersebut, meskipun partisipan dalam penelitian ini berasal dari rentang usia berbeda dan tentunya memiliki rutinitas yang berbeda pula, tidak menutup kemungkinan bahwa partisipan melakukan hal yang sama seperti hasil penelitian tersebut yang dapat mengganggu fokus mereka dalam beraktivitas dan dapat menimbulkan stres. Hal inilah yang memungkinkan aspek trust in one's instincts, tolerance of negative affect, and strengthening effects of stress berkorelasi dengan infertility-related stress.

Aspek ketiga yang berkorelasi langsung dengan infertility-related stress adalah positive acceptance of change, and secure relationships. Penelitian yang dilakukan oleh Hapsari \& Septiani (2015) menyatakan bahwa wanita yang mengalami infertilitas harus mampu menerima kritik sosial dan beradaptasi pada lingkungan masyarakat yang berorientasi pada anak. Proses penerimaan kritik dan upaya untuk beradaptasi dengan lingkungan tentunya bukan hal yang mudah. Hal ini mungkin saja terjadi pada partisipan dalam penelitian ini, yang jika mereka gagal untuk mampu menerima kritik dan beradaptasi dengan lingkungan terkait infertilitas, tentunya akan menimbulkan stres bagi individu tersebut (Folkman \& Lazarus, 1984).

Kemudian terdapat dua aspek dari resiliensi yang tidak berkorelasi dengan infertility-related stress, yakni self-control dan spiritual influences. Terkait dengan aspek self-control, penelitian yang dilakukan oleh Jebraeili, Hashemi, \& Nazemi (2016) menyatakan bahwa ketika wanita yang mengalami infertilitas mampu mengontrol dirinya dan mendapatkan dukungan positif dari orang sekitarnya, maka infertilitas yang dialami tidak terlalu menimbulkan stres bagi dirinya. Selanjutnya, terkait dengan spiritual influences, 
penelitian yang dilakukan oleh Domar, et al. (2005) menyatakan bahwa wanita yang mengalami infertilitas yang memiliki kepercayaan agama atau spiritual yang tinggi, mencapai relaksasi, memiliki perasaan bersama dalam artian selalu di dilindungi oleh tuhan dan menghilangkan stres yang dialami terkait infertilitas melalui doa. Berdasarkan hal tersebut tidak tertutup kemungkinan bahwa sebagian besar partisipan dalam penelitian ini memiliki kontrol diri (self-control) dan religiusitas (spiritual influences) tinggi yang menyebabkan kedua aspek tersebut tidak berkorelasi dengan infertility-related stress dalam penelitian ini. Dalam penelitian ini, peneliti melakukan uji tabulasi silang antara infertility-related stress dengan data demografi partisipan.

Tabel 4. Tabulasi Silang IRS dengan Usia Partisipan

\begin{tabular}{ccccc}
\hline \multirow{2}{*}{$\begin{array}{c}\text { Usia } \\
\text { Tahun })\end{array}$} & \multicolumn{4}{c}{ Kategorisasi Infertility-Related Stress } \\
\cline { 2 - 5 } $21-30$ & Rendah & Sedang & Tinggi & Total \\
\hline & $\begin{array}{c}11 \\
(9.2 \%)\end{array}$ & $\begin{array}{c}43 \\
(36.1 \%)\end{array}$ & $\begin{array}{c}2 \\
(1.7 \%)\end{array}$ & 56 \\
\hline $31-40$ & 10 & 30 & 10 & 50 \\
& $(8.5 \%)$ & $(25.2 \%)$ & $(8.5 \%)$ & \\
\hline $41-50$ & 3 & 8 & 1 & 12 \\
& $(2.5 \%)$ & $(6.7 \%)$ & $(0.8 \%)$ & \\
\hline $51-60$ & 1 & 0 & 0 & 1 \\
& $(0.8 \%)$ & & & 119 \\
\hline Total & 25 & 81 & 13 & \\
\hline
\end{tabular}

Berdasarkan tabel di atas, uji tabulasi silang infertility-related stress dengan usia kronologis partisipan di atasmenunjukkan bahwa partisipan yang memiliki tingkat infertility-related stress dengan kategori sedang dan tinggi terdapat pada rentang usia 21 sampai 30 tahun dan 31 sampai 40 tahun. Oleh karena itu, penelitian ini sejalan dengan hasil penelitian yang ditemukan oleh Boivin, et al. (2007) bahwa usia wanita yang rentan mengalami infertilitas adalah usia 30-37 tahun sehingga stres infertilitas yang dialami akan berlangsung selama rentang usia tersebut. Sedangkan pada wanita yang mengalami infertilitas dengan tingkat stres yang rendah, hal ini menandakan bahwa dirinya telah sampai pada tahap resolution of infertility di mana mereka mampu menerima keadaan dirinya (acceptance) dan mau terbuka dengan berbagai solusi (Tedjawidjaja \& Rahardanto, 2015).

Tabel 5. Tabulasi Silang IRS dengan Usia Pernikahan

\begin{tabular}{ccccc}
\hline \multirow{2}{*}{$\begin{array}{c}\text { Usia } \\
\text { Pernikahan } \\
\text { (Tahun) }\end{array}$} & \multicolumn{4}{c}{ Kategorisasi Infertility-Related Stress } \\
\cline { 2 - 5 } & Rendah & Sedang & Tinggi & Total \\
\hline $1-5$ & $\begin{array}{c}18 \\
(15.1 \%)\end{array}$ & $\begin{array}{c}57 \\
(47.9 \%)\end{array}$ & $\begin{array}{c}9 \\
(7.6 \%)\end{array}$ & 84 \\
\hline $6-10$ & $\begin{array}{c}2 \\
(1.7 \%)\end{array}$ & $\begin{array}{c}20 \\
(16.8 \%)\end{array}$ & $\begin{array}{c}(3.4 \%) \\
4\end{array}$ & 26 \\
\hline $11-15$ & $\begin{array}{c}3 \\
(2.5 \%)\end{array}$ & $\begin{array}{c}3 \\
(2.5 \%)\end{array}$ & 0 & 6 \\
\hline $16-20$ & $\begin{array}{c}2 \\
(1.7 \%)\end{array}$ & $\begin{array}{c}1 \\
(0.8 \%)\end{array}$ & 0 & 3 \\
\hline Total & 25 & 81 & 13 & 119 \\
\hline
\end{tabular}

Berdasarkan tabel di atas, hasil uji tabulasi silang antara infertility-related stress dengan usia pernikahan dalam penelitian ini juga menunjukkan hasil bahwa partisipan terbanyak yang memiliki infertility-related stress kategori sedang dan tinggi terdapat pada rentang usia pernikahan 1 sampai 5 tahun dan 6 sampai 10 tahun. Penelitian yang dilakukan oleh Elvina \& Maulina (2015) juga menemukan bahwa usia pernikahan $2-5$ tahun menjadi usia kritis yang dapat menimbulkan stres ketika pasangan dihadapkan 
dengan situasi infertilitas. Hal ini dikarenakan terjadinya sesuatu yang bertolak belakang dengan tugas perkembangan individu untuk memulai keluarga dan memiliki keturunan.

Tabel 6. Tabulasi Silang IRS dengan Durasi Pernikahan

\begin{tabular}{|c|c|c|c|c|}
\hline \multirow{2}{*}{$\begin{array}{c}\text { Durasi } \\
\text { (Tahun) }\end{array}$} & \multicolumn{4}{|c|}{ Kategorisasi Infertility-Related Stress } \\
\hline & Rendah & Sedang & Tinggi & Total \\
\hline $1-5$ & $\begin{array}{c}18 \\
(15.1 \%)\end{array}$ & $\begin{array}{c}60 \\
(50.4 \%)\end{array}$ & $\begin{array}{c}9 \\
(7.6 \%)\end{array}$ & 87 \\
\hline $6-10$ & $\begin{array}{c}4 \\
(3.4 \%)\end{array}$ & $\begin{array}{c}17 \\
(14.3 \%)\end{array}$ & $\begin{array}{c}4 \\
(3.4 \%)\end{array}$ & 25 \\
\hline $11-15$ & $\begin{array}{c}2 \\
(1.7 \%)\end{array}$ & $\begin{array}{c}3 \\
(2.5 \%)\end{array}$ & 0 & 5 \\
\hline $16-20$ & $\begin{array}{c}1 \\
(0.8 \%)\end{array}$ & $\begin{array}{c}1 \\
(0.8 \%)\end{array}$ & 0 & 2 \\
\hline Total & 25 & 81 & 13 & 119 \\
\hline
\end{tabular}

Kemudian berdasarkan tabel hasil uji tabulasi silang yang juga dilakukan oleh peneliti antara infertility-related stress dengan durasi infertilitas partisipan di atas, ditemukan bahwa partisipan terbanyak dalam kategori sedang dan tinggi terdapat pada rentang durasi pernikahan satu sampai lima tahun. Hal ini juga sejalan dengan penelitian yang dilakukan oleh Domar et al. (1992) bahwa wanita yang mengalami infertilitas dengan durasi dua sampai tiga tahun memiliki tingkat stres dan depresi yang lebih tinggi dibandingkan dengan durasi lainnya. Hal ini dikarenakan selama tiga tahun pertama mengalami infertilitas akan muncul tanda-tanda kecemasan, depresi, kehilangan harga diri, impotensi, stres dan ketidakcocokan akan status perkawinan. Hasil dalam penelitian ini juga menunjukkan bahwa terdapat penurunan jumlah partisipan yang mengalami stres di semua kategori pada durasi infertilitas enam sampai 20 tahun. Hal ini dikarenakan adanya perubahan sikap optimis menjadi putus asa atau meningkatnya penerimaan di dalam dirinya terkait dengan keadaan infertilitas yang dialami setelah menunggu dalam waktu yang sangat lama (Ardenti et al., 1999).

\section{SIMPULAN}

Hasil penelitian ini menunjukkan bahwa terdapat korelasi negatif antara resiliensi dengan infertility-related stress pada wanita yang mengalami infertilitas di Bali. Peneliti juga melakukan uji korelasi terhadap kelima aspek resiliensi dengan infertility-related stress di mana terdapat tiga aspek yang memiliki korelasi dengan dua aspek yang tidak berkorelasi langsung. Adapun aspek pertama yang berkorelasi yaitu personal competence, high standards, and tenacity, berkaitan dengan kemampuan yang dimiliki wanita yang mengalami infertilitas dalam menghadapi dampak dari infertilitas yang dialami. Adanya kemampuan yang berbeda pada setiap partisipan ini membuat aspek tersebut berkorelasi dengan infertility-related stress.

Kemudian aspek kedua yang berkorelasi dengan infertility-related stress yaitu trust in one's instincts, tolerance of negative affect, and strengthening effects of stress. Dalam penelitian ini, aspek tersebut berkaitan dengan ketenangan dan fokus wanita yang mengalami infertilitas dalam menjalani rutinitas sehari-hari. Infertilitas yang dianggap sebagai sesuatu yang menimbulkan stres dan dapat memengaruhi rutinitas bagi yang mengalaminya, kemungkinan menjadi penyebab aspek tersebut berkorelasi dengan infertility-related stress. Kemudian aspek ketiga yang berkorelasi dengan infertilityrelated stress yaitu positive acceptance of change and secure relationships. Dalam penelitian ini, aspek tersebut berkaitan dengan penerimaan positif dan kemampuan adaptasi pada wanita yang mengalami infertilitas terkait dengan kondisi yang dialami. Adanya perbedaan kemampuan individu dalam melakukan penerimaan diri dan adaptasi dengan kondisi infertilitasnya membuat aspek tersebut berkorelasi dengan infertility-related stress.

Adapun dua aspek yang tidak berkorelasi dengan infertility-related stress, yaitu self-control yang berkaitan dengan kontrol diri dan dukungan positif dari orang terdekat terhadap wanita yang mengalami 
infertilitas dan spiritual infuences terkait dengan partisipan yang mampu menghilangkan stres infertilitasnya melalui doa. Oleh karena itu, tidak tertutup kemungkinan bahwa sebagian besar partisipan memiliki self-control dan spiritual influences yang tinggi yang membuat kedua aspek tersebut tidak berkorelasi dengan infertility-related stress.

Terdapat beberapa saran yang diberikan oleh peneliti kepada peneliti selanjutnya yang akan melakukan penelitian terkait dengan topik resiliensi dan infertility-related stress. Adapun saran tersebut yaitu penyebaran kuesioner diharapkan dapat dilakukan secara langsung untuk membangun rapport yang baik dengan partisipan dan sekaligus melakukan observasi terhadap partisipan.

Peneliti selanjutnya diharapkan memperoleh jumlah partisipan wanita yang mengalami infertilitas secara merata agar hasilnya dapat mewakili seluruh kabupaten yang ada di Bali. Peneliti selanjutnya diharapkan dapat menambah jumlah partisipan untuk dapat memenuhi kenormalitasan data sesuai dengan teori yakni kenormalitasan data dapat dicapai dengan jumlah partisipan minimal sebanyak 200. Penelitian selanjutnya diharapkan dapat melakukan penelitian terkait resiliensi dan infertility-related stress menggunakan metode kualitatif untuk mengetahui kedua hal tersebut pada wanita yang mengalami infertilitas secara lebih mendalam.

Selanjutnya, partisipan dalam penelitian ini diharapkan dapat memahami kondisi yang dialami sebagai suatu cobaan yang harus dihadapi dengan positif, sedangkan untuk orang terdekat dari partisipan diharapkan tetap memberikan semangat dan senantiasa mendampingi agar partisipan tidak merasa sendiri menghadapi kondisi yang dialaminya.

\section{DAFTAR PUSTAKA}

The Practice Committee American Society for Reproductive Medicine (ASRM). (2006). Aging and infertility in women. Fertility and Sterility, 86(4), 248-252.

Apfel, R. J., \& Keylor, R. G. (2002). Psychoanalysis and infertility myths and realities. The International Journal of Psychoanalysis, 83(1), 85-104.

Ardenti, R., Campari, C., Agazzi, L., \& La Sala, G. B. (1999). Anxiety and perceptive functioning of infertile women during in-vitro fertilization: exploratory survey of an Italian sample. Human Reproduction, 14(12), 3126-3132.

Ayu, I. B. (2012). Resiliensi pada wanita yang mengalami abortus spontanea. Jurnal Penelitian dan Pengukuran Psikologi, 1(1), 71-77.

Azzahra, F. (2017). Pengaruh resiliensi terhadap distres psikologis pada mahasiswa. Jurnal Ilmiah Psikologi Terapan, 5(1), 80-96.

Boivin, J., Bunting, L., Collins, J. A., \& Nygren, K. G. (2007). International estimates of infertility prevalence and treatment-seeking: potential need and demand for infertility medical care. Human Reproduction, 22(6), 1506-1512.

Connor, K. M., \& Davidson, J. R. (2003). Development of a new resilience scale: The Connor-Davidson resilience scale (CD-RISC). Depression and Anxiety, 18(2), 76-82.

Dewi, F.P. (2014). Konstruksi sosial keluarga tanpa anak (studi deskriptif tentang makna keluarga tanpa anak dan stigma yang dialami oleh pasangan suami istri tanpa anak di Surabaya). Journal of University of Airlangga, 3(1), 1-20.

Domar, A. D., Broome, A., Zuttermeister, P. C., Seibel, M., \& Friedman, R. (1992). The prevalence and predictability of depression in infertile women. Fertility and Sterility, 58(6), 1158-1163.

Domar, A. D., Penzias, A., Dusek, J. A., Magna, A., Merarim, D., Nielsen, B., \& Paul, D. (2005). The stress and distress of infertility: Does religion help women cope?. Sexuality, Reproduction and Menopause, 3(2), 45-51.

Elvina, E. \& Maulina, V. V. R. (2015). Gambaran self-esteem pada pasangan suami-istri yang mengalami infertilitas. Jurnal Konseling dan Keluarga, 72-85.

Estherline, S. H., \& Widayanti, C. G. (2016). Makna infertilitas bagi istri dalam keluarga jawa. Jurnal EMPATI, 5(2), 276-281.

Folkman, S. \& Lazarus, R. S.(1984). Personal control and stress and coping processes: A theoretical analysis. Journal of Personality and Social Psychology, 46(4), 839-852.

Fraenkel, J. R., Wallen, N. E., \& Hyun, H. H. (2012). How to design and evaluate research in education. New York: McGraw-Hill Education. 
Hapsari, I. I., \& Septiani, S. R. (2015). Kebermaknaan hidup pada wanita yang belum memiliki anak tanpa disengaja (involuntary childless). Jurnal Penelitian dan Pengukuran Psikologi, 4(2), 90-100.

Herrmann, D., Scherg, H., Verres, R., Hagens, C. V., Strowitzki, T., \& Wischmann, T. (2011). Resilience in infertile couples acts as a protective factor against infertility-specific distress and impaired quality of life. Journal of Assisted Reproduction and Genetics, 28(11), 1111-1117.

Herrman, H., Stewart, D. E., Diaz-Granados, N., Berger, E. L., Jackson, B., \& Yuen, T. (2011). What is resilience?. The Canadian Journal of Psychiatry, 56(5), 258-265.

Hidayah, N. (2007). Identifikasi dan pengelolaan stres infertilitas. Humanitas, 4(1), 25-33.

Indriyani, D. (2011). Konseling infertilitas. The Indonesian Journal of Health Science, 1(2), 83-94.

Jebraeili, H., Hashemi, J., \& Nazemi, A. (2016). A comparative study of resilience, meta-emotional beliefs, and psychological well-being in fertile and infertile women. Journal of Fundamentals of Mental Health, 18(5), 259-264.

Jordan, C., \& Revenson, T. A. (1999). Gender differences in coping with infertility: a meta-analysis. Journal of Behavioral Medicine, 22(4), 341-358.

Kasdu, D. (2002). Kiat Sukses Pasangan Memperoleh Keturunan. Jakarta: Pustaka Pembangunan Swadaya Nusantara.

Keye, M. D. \& Pidgeon, A. M. (2013). Investigation of the relationship between resilience, mindfulness, and academic self-efficacy. Open Journal of Social Sciences, 1(6), 1-4.

Komalasari, G., \& Septiyanti, R. (2017). Koping stres wanita menikah yang belum dikaruniai anak. Jurnal Penelitian dan Pengukuran Psikologi, 6(2), 61-65.

Lestari, S. W., \& Sari, T. (2015). Fragmentasi DNA spermatozoa: penyebab, deteksi, dan implikasinya pada infertilitas laki-laki. eJournal Kedokteran Indonesia, 3(2), 152-160.

Li, Y., Zhang, X., Shi, M., Guo, S., \& Wang, L. (2019). Resilience acts as a moderator in the relationship between infertility-related stress and fertility quality of life among women with infertility: a crosssectional study. Health and Quality of Life Outcomes, 17(38), 1-9.

Mardiyan, R., \& Kustanti, E. R. (2016). Kepuasan pernikahan pada pasangan yang belum memiliki keturunan. Jurnal Empati, 5(3), 558-565.

Maryuliana, Subroto, I. M. I., \& Haviana, S. F. C. (2016). Sistem informasi angket pengukuran skala kebutuhan materi pembelajaran tambahan sebagai pendukung pengambilan keputusan di sekolah menengah atas menggunakan skala likert. Jurnal Transistor Elektro dan Informatika (TRANSISTOR EI), 1(2), 1-12.

Masten, A. S. (2007). Resilience in developing systems: Progress and promise as the fourth wave rises. Development and Psychopathology, 19(3), 921-930.

Mengintip perang tarif program bayi tabung di Bali, paling murah Rp 37 juta, termahal Rp 70 juta (2018, 24 September). Tribun News, 1-4. https://www.tribunnews.com/regional/2018/09/24/mengintipperang-tarif-program-bayi-tabung-di-bali-paling-murah-rp-37-juta-termahal-rp-70-juta

Musa, R., et al.(2014). A preliminary study of the psychological differences in infertile couples and their relation to the coping styles. Comprehensive Psychiatry, 55, S65-S69.

Newton, C. R., Sherrard, W., \& Glavac, I. (1999). The fertility problem inventory: measuring perceived infertility-related stress. Fertility and Sterility, 72(1), 54-62.

Nurkhasanah, S. (2016). Hubungan infertil dengan respon psikologis istri yang mengalami infertil di kota Padang tahun 2015. Jurnal Kesehatan STIKes Prima Nusantara Bukittinggi, 7(1), 10-15.

Nurhasyanah. (2012). Faktor-faktor yang mempengaruhi penerimaan diri pada wanita infertilitas. Jurnal Penelitian dan Pengukuran Psikologi, 1(1), 143-152.

Pandanwati, I. S., \& Suprapti, V. (2012). Resiliensi keluarga pada pasangan dewasa madya yang tidak memiliki anak kandung. Jurnal Psikologi Pendidikan dan Perkembangan, 1(3), 1-8.

Periantalo, J. (2016). Penelitian Kuantitatif untuk Psikologi. Yogyakarta: Pustaka Pelajar.

Prasanti, M. D. (2013). Nilai anak pada ibu dengan status sosial ekonomi tinggi ditinjau dari etnis Jawa. Calyptra: Jurnal Ilmiah Mahasiswa Universitas Surabaya, 2(1), 1-15.

Ratna, J. M. J. (2000). The influence of causative factors on coping strategy and level of depression among indonesian couples receiving a diagnosis of infertility. Jurnal Psikologi Indonesia Anima, 15(4), $303-331$.

Reivich, K., \& Shatte, A. (2002). The Resilience Factor: 7 Keys to Finding Your Inner Strength and Overcoming Life's Hurdles. New York: Three Rivers Press. 
Rojas, L. F. (2015). Factors affecting academic resilience in middle school students: a case study. Gist: Education and Learning Research Journal, 11, 63-78.

Saraswati, A. (2015). Infertility. J MAJORITY, 4(5), 5-9.

Schmidt, L. (2006). Infertility and assisted reproduction in denmark. Danish Medical Bulletin, 53(4), 390417.

Sexton, M. B., Byrd, M. R. \& Kluge, S. V. (2010). Measuring resilience in women experiencing infertility using the CD-RISC: Examining infertility-related stress, general distress, and coping styles. Journal of Psychiatric Research, 44(4), 236-241.

Sobral, M. P., Costa, M. E., Schmidt, L., \& Martins, M. V. (2017). COMPI fertility problem stress scales is a brief, valid and reliable tool for assessing stress in patients seeking treatment. Human Reproduction, 32(2), 375-382.

Subagyo, P., \& Djarwanto. (2005). Statistika Induktif. Yogyakarta: BPFE Yogyakarta.

Sugiyono. (2016). Metode Penelitian Kuantitatif, Kualitatif, dan R\&D. Bandung: Alfabeta.

Supardi. (1993). Populasi dan sampel penelitian. UNISIA, 17, 100-108.

Susanti, S., \& Nurchayati. (2019). Menikah tanpa keturunan: masalah psikologis yang dialami perempuan menikah tanpa anak dan strategi coping dalam mengatasinya. Character: Jurnal Penelitian Psikologi, 6(1), 1-13.

Tedjawidjaja, D., \& Rahardanto, M. S. (2015). Antara harapan dan takdir: resolution to infertility pada perempuan infertil. Jurnal Experientia, 3(1), 109-119.

Ulfah, S. M., \& Mulyana, O. P. (2014). Gambaran subjective well being pada wanita involuntary childless. Character, 2(3), 1-10.

World Health Organisation Infertility. (2012). A tabulation of available data on prevalence of primary and secondary infertility1991Geneva. WHO Programme on Maternal and Child Health.

Wiweko, B. (2018). Inovasi kedokteran reproduksi pada era disrupsi. eJournal Kedokteran Indonesia, 6(3), $151-158$.

Yani, I. (2018). Harmonisasi keluarga pasangan suami istri yang tidak memiliki keturunan di desa bangun jaya kecamatan tambusai utara kabupaten rokan hulu. Jurnal Online Mahasiswa Fakultas Ilmu Sosial dan Ilmu Politik Universitas Riau, 5(1), 1-14.

Zurlo, M. C., Volta, M. F. C. D., \& Vallone, F. (2017). Factor structure and psychometric properties of the fertility problem inventory-short form. Health Psychology Open, 4(2), 1-11. 